\title{
Correction
}

\section{Behavioral symptoms in mild cognitive impairment}

In the brief communication "Behavioral symptoms in mild cognitive impairment" (Neurology 2004;62:1199-1201) by Feldman et al., the authors have an error in the Methodology section. The less than sign should have been the greater than sign in the following sentence: "Exclusions to the study included a 17-item Hamilton Rating Scale for Depression (HAM-D) score of $>13$, a HAM-D Item 1 (depressed mood) score $\geq 1$, or a DSM-IV major depression diagnosis at the time of screening." The authors apologize for this error. 


\section{Neurology}

In the brief communication "Behavioral symptoms in mild cognitive impairment" ( Neurology 2004;62:1199-1201) by Feldman et al., the authors have an error in the Methodology section.

Neurology 2004;63;764

DOI 10.1212/WNL.63.4.764

This information is current as of August 23, 2004

Updated Information \& Services

Permissions \& Licensing

Reprints including high resolution figures, can be found at: http://n.neurology.org/content/63/4/764.full

Information about reproducing this article in parts (figures,tables) or in its entirety can be found online at:

http://www.neurology.org/about/about_the_journal\#permissions

Information about ordering reprints can be found online:

http://n.neurology.org/subscribers/advertise

Neurology ${ }^{\circledR}$ is the official journal of the American Academy of Neurology. Published continuously since 1951, it is now a weekly with 48 issues per year. Copyright . All rights reserved. Print ISSN: 0028-3878. Online ISSN: 1526-632X.

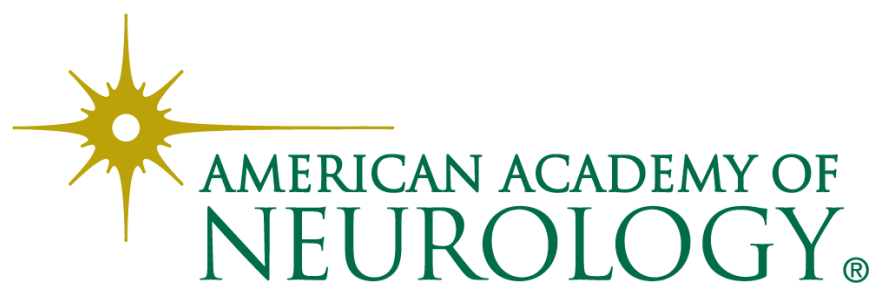

